Article

\title{
Anti-Neuroinflammatory ent-Kaurane Diterpenoids from Pteris multifida Roots
}

\author{
Jung Wha Kim, Ji Yeon Seo, Won Keun Oh and Sang Hyun Sung * \\ College of Pharmacy and Research Institute of Pharmaceutical Science, Seoul National University, Seoul 08826, \\ Korea; jkim11@snu.ac.kr (J.W.K.); quftkfka@gmail.com (J.Y.S.); wkoh1@snu.ac.kr (W.K.O.) \\ * Correspondence: shsung@snu.ac.kr; Tel.: +82-2-880-7859
}

Academic Editors: Quan-Bin Han and Jian-Xin Pu

Received: 29 November 2016; Accepted: 22 December 2016; Published: 26 December 2016

\begin{abstract}
Activated microglia are known to be a major source of cellular neuroinflammation which causes various neurodegenerative diseases, including Alzheimer's disease. In our continuing efforts to search for new bioactive phytochemicals against neuroinflammatory diseases, the $80 \%$ methanolic extract of Pteris multifida (Pteridaceae) roots was found to exhibit significant NO inhibitory activity in lipopolysaccharide (LPS)-activated BV-2 microglia cells. Three new ent-kaurane diterpenoids, pterokaurane $\mathrm{M}_{1}$ 2-O- $\beta$-D-glucopyranoside (4), 2 $\beta, 16 \alpha$-dihydroxy-ent-kaurane 2,16-di-O- $\beta$-Dglucopyranoside (10), and $2 \beta, 16 \alpha, 17$-trihydroxy-ent-kaurane 2-O- $\beta$-D-glucopyranoside (12), were isolated along with nine other known compounds from $P$. multifida roots. The chemical structures of the new compounds were determined by 1D- and 2D-NMR, HR-ESI-MS, and CD spectroscopic data analysis. Among the isolates, compounds 1 and 7 significantly inhibited NO production in LPS-stimulated BV-2 cells reducing the expression of the cyclooxygenase-2 (COX-2) protein and the level of pro-inflammatory mediators such as prostaglandin $\mathrm{E}_{2}\left(\mathrm{PGE}_{2}\right)$, tumor necrosis factor (TNF)- $\alpha$, interleukin (IL)-1 $\beta$, and IL-6. These results suggest that ent-kaurane diterpenes from P. multifida could be potential lead compounds that act as anti-neuroinflammatory agents.
\end{abstract}

Keywords: Pteris multifida; ent-kaurane diterpenoids; anti-neuroinflammation; nitric oxide (NO); BV-2 microglia

\section{Introduction}

Microglia are resident immune cells in the central nervous system [1]. In response to external stimuli such as lipopolysaccharides (LPS), they release various types of inflammatory molecules including nitric oxide (NO) [2]. In the brain, $\mathrm{NO}$ acts as a neuromodulator at synaptic junctions; however, high levels of NO produced by activated microglia induce oxidative stress and inflammation [3]. Neuroinflammation is associated with the pathogenesis and progression of neurodegenerative diseases such as Alzheimer's disease, Parkinson's disease and multiple sclerosis [4].

During our continuing search for bioactive substances from medicinal plants that act against neuroinflammation, an $80 \%$ methanol extract of Pteris multifida Poir. (Pteridaceae) roots was found to significantly inhibit lipopolysaccharide (LPS)-induced NO production ( $\mathrm{IC}_{50} 18.6 \mu \mathrm{g} / \mathrm{mL}$ ). P. multifida is a perennial fern found in the southeast of China, Japan and South Korea [5,6]. As a folk medicine in China, the whole plant has been used to treat dysentery, cholecystitis, hepatitis, eczema, rheumatism, hematemesis, enteritis, and diarrhea [5,7]. Previous studies on the chemical constituents of P. multifida have revealed the presence of diterpenoids, sesquiterpenoids, flavonoids, coumarins, lignans, and sterols [5-10]. Recent studies have reported that the extract and constituents of P. multifida showed anti-tumor, anti-hyperlipidemic, and free radical-scavenging activities [11-13]. To the best of our knowledge, however, there have been no reports on any anti-neuroinflammatory activity of $P$. multifida. In the present study, we identified bioactive chemical constituents of $P$. multifida 
with NO inhibitory effects. We isolated 12 ent-kaurane diterpenoids 1-12 (Figure 1) including three new compounds, pterokaurane $\mathrm{M}_{1}$ 2-O- $\beta$-D-glucopyranoside (4), $2 \beta, 16 \alpha$-dihydroxy-ent-kaurane 2,16-di-O- $\beta$-D-glucopyranoside (10), and 2 $\beta, 16 \alpha, 17$-trihydroxy-ent-kaurane 2-O- $\beta$-D-glucopyranoside (12), and evaluated the NO inhibitory activity of all the isolates on LPS-activated BV-2 microglia cells.
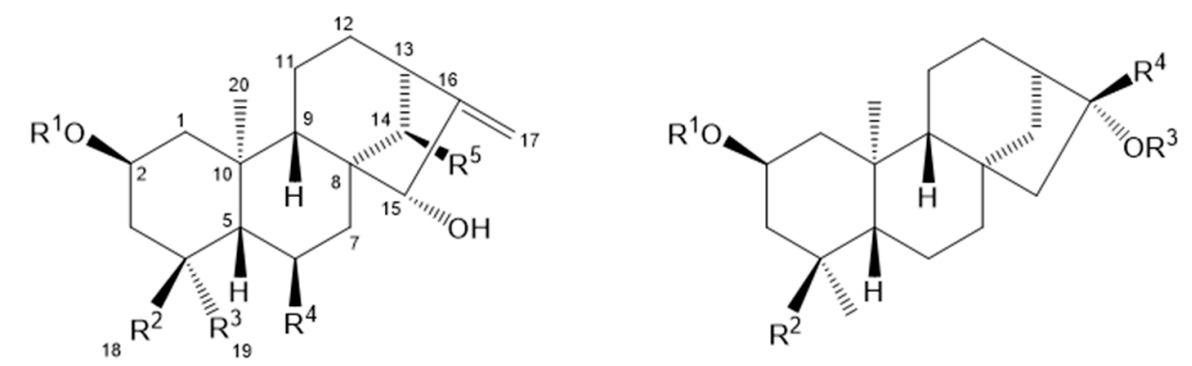

$\begin{array}{lccccc} & \mathrm{R}^{1} & \mathrm{R}^{2} & \mathrm{R}^{3} & \mathrm{R}^{4} & \mathrm{R}^{5} \\ \mathbf{1} & \mathrm{H} & \mathrm{CH}_{3} & \mathrm{CH}_{3} & \mathrm{H} & \mathrm{H} \\ \mathbf{3} & \beta \text {-D-Glc } & \mathrm{CH}_{3} & \mathrm{CH}_{3} & \mathrm{H} & \mathrm{H} \\ \mathbf{4} & \beta \text {-D-Glc } & \mathrm{CH}_{2} \mathrm{OH} & \mathrm{CH}_{3} & \mathrm{H} & \mathrm{H} \\ \mathbf{5} & \beta \text {-D-Glc } & \mathrm{CH}_{3} & \mathrm{CH}_{2} \mathrm{OH} & \mathrm{H} & \mathrm{H} \\ \mathbf{6} & \mathrm{H} & \mathrm{CH}_{3} & \mathrm{CH}_{3} & \mathrm{OH} & \mathrm{H} \\ \mathbf{7} & \mathrm{H} & \mathrm{CH}_{3} & \mathrm{CH}_{3} & \mathrm{H} & \mathrm{OH} \\ \mathbf{8} & \beta \text {-D-Glc } & \mathrm{CH}_{3} & \mathrm{CH}_{3} & \mathrm{H} & \mathrm{OH}\end{array}$

$\begin{array}{ccccc} & \mathrm{R}^{1} & \mathrm{R}^{2} & \mathrm{R}^{3} & \mathrm{R}^{4} \\ 9 & \mathrm{H} & \mathrm{CH}_{3} & \mathrm{H} & \mathrm{CH}_{3} \\ 10 & \beta \text {-D-Glc } & \mathrm{CH}_{3} & \beta \text {-D-Glc } & \mathrm{CH}_{3} \\ 11 & \mathrm{H} & \mathrm{CH}_{2} \mathrm{OH} & \mathrm{H} & \mathrm{CH}_{3} \\ 12 & \beta \text {-D-Glc } & \mathrm{CH}_{3} & \mathrm{H} & \mathrm{CH}_{2} \mathrm{OH}\end{array}$

Figure 1. Chemical structures of the isolated compounds 1-12 from P. multifida.

\section{Results and Discussion}

\subsection{Isolation and Characterization of the Ent-Kaurane Diterpenoids}

Compound 4 was isolated as a white amorphous powder, and the molecular formula, $\mathrm{C}_{26} \mathrm{H}_{42} \mathrm{O}_{8}$, was established by a HR-ESI-MS peak in the positive ion mode at $m / z 483.2963[\mathrm{M}+\mathrm{H}]^{+}$(calcd. for $\left.\mathrm{C}_{26} \mathrm{H}_{43} \mathrm{O}_{8}, 483.2958\right)$ and by the NMR spectrum. Acid hydrolysis of 4 yielded glucose which had the same retention time as D-glucose in a HPLC experiment [14]. The ${ }^{1} \mathrm{H}-$ and ${ }^{13} \mathrm{C}-\mathrm{NMR}$ spectrum of 4 showed resonances attributed to an olefinic group $\left[\delta_{\mathrm{H}} 5.17(1 \mathrm{H}, \mathrm{s}), 5.06(1 \mathrm{H}, \mathrm{s}) ; \delta_{\mathrm{C}} 109.8\right]$, two tertiary methyl groups $\left[\delta_{\mathrm{H}} 1.13(3 \mathrm{H}, \mathrm{s}), 0.79(3 \mathrm{H}, \mathrm{s}) ; \delta_{\mathrm{C}} 20.6,19.5\right]$ and a $\beta$-glucopyranose group [ $\delta_{\mathrm{H}} 4.38\left(1 \mathrm{H}, \mathrm{d}, J=7.8 \mathrm{~Hz}, \mathrm{H}-1^{\prime}\right)$; $\left.103.3\left(\mathrm{C}-1^{\prime}\right), 78.9\left(\mathrm{C}-5^{\prime}\right), 78.6\left(\mathrm{C}-3^{\prime}\right), 75.9\left(\mathrm{C}-2^{\prime}\right), 72.5\left(\mathrm{C}-4^{\prime}\right), 63.6\left(\mathrm{C}-6^{\prime}\right)\right]$. The ${ }^{13} \mathrm{C}$-NMR spectrum of 4 exhibited 20 carbon signals for an aglycone, which were resolved into two methyls $\left(\delta_{C} 20.6,19.5\right)$, nine methylenes $\left(\delta_{C} 109.8,72.7,49.1,43.0,38.2,36.8,34.7,20.7,20.1\right)$, five methines $\left(\delta_{C} 84.6,74.9,56.6,50.5,44.5\right)$, and four quaternary carbons, suggesting that 4 contains an ent-kaurane diterpene skeleton. Comparisons of the ${ }^{13} \mathrm{C}$-NMR spectroscopic data of 4 with those reported for the ent-kaurane diterpene pterokaurane $\mathrm{M}_{1}(3)$ revealed extensive similarities, except for the additional signals of a glucose moiety [8]. The ${ }^{1} \mathrm{H}-{ }^{1} \mathrm{H}$ COSY and HMQC spectra of 4 showed the correlation signals of partial structural fragments of $-\mathrm{CH}_{2} \mathrm{CHCH}_{2}-(\mathrm{C}-1-\mathrm{C}-2-\mathrm{C}-3),-\mathrm{CHCH}_{2} \mathrm{CH}_{2}-$ (C-5-C-6-C-7), and - $\mathrm{CH}_{2} \mathrm{CH}_{2} \mathrm{CHCH}_{2}-(\mathrm{C}-11-\mathrm{C}-12-\mathrm{C}-13-\mathrm{C}-14)$ (Figure 2a). The HMBC correlations from $\mathrm{H}-5\left(\delta_{\mathrm{H}} 1.20, \mathrm{~m}\right)$ to $\mathrm{C}-1, \mathrm{C}-4, \mathrm{C}-9, \mathrm{C}-10, \mathrm{CH}_{3}-19$, and $\mathrm{CH}_{3}-20$ and from $\mathrm{H}-15\left(\delta_{\mathrm{H}} 3.76\right.$, br s) to C-8, C-9, C-13, C-14, C-16, and C-17 support that 4 possesses an ent-kaurane skeleton (Figure 2a). Additionally, the correlations from H-17 $\left[\delta_{\mathrm{H}} 5.07(1 \mathrm{H}, \mathrm{s}), 5.17(1 \mathrm{H}, \mathrm{s})\right]$ to $\mathrm{C}-12, \mathrm{C}-13, \mathrm{C}-15$, and C-16 reveal the presence of an exomethylene group on $\mathrm{C}-16$, and the correlations from $\mathrm{H}-1^{\prime}\left(\delta_{\mathrm{H}} 4.38\right)$ to $\mathrm{C}-2$ imply that the sugar moiety is attached to C-2. In the NOESY spectrum, the correlation signals from $\mathrm{H}-2$ with $\mathrm{CH}_{3}-19,20$ and from $\mathrm{CH}_{3}-20$ to $\mathrm{H}-14$ reveal that the $O$-glucose group at $\mathrm{C}$-2 is $\beta$-oriented, and the signals from $\mathrm{H}-17$ to H-15a, H-15a to H-9, and H-9 to H-5 establish that the hydroxyl group at C-15 is $\alpha$-oriented, respectively (Figure 3a) [15]. Moreover, the interatomic distances measured on the $3 \mathrm{D}$ structure of the aglycone of 4 in the ChemBio3D software support the above determination of 
the relative configurations (Figure 3a). The absolute configuration of 4 was elucidated from the CD spectra, which showed a negative cotton effect at $298 \mathrm{~nm}$ and a positive one at $325 \mathrm{~nm}$, confirming that the stereochemistry of C-5 was a S-configuration (Figure S7) [15]. Based on the above data, compound 4 was determined to be pterokaurane $\mathrm{M}_{1} 2-O-\beta-\mathrm{D}$-glucopyranoside.

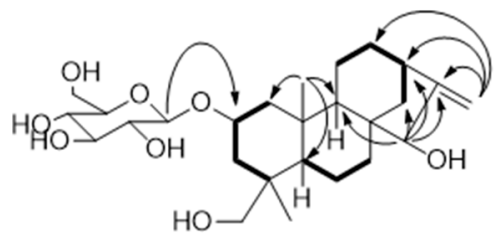

(a)

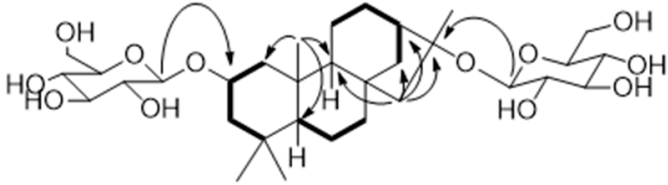

(b)

Figure 2. Key COSY (bold line) and HMBC (plain arrow) correlations of compounds 4 (a) and 10 (b).

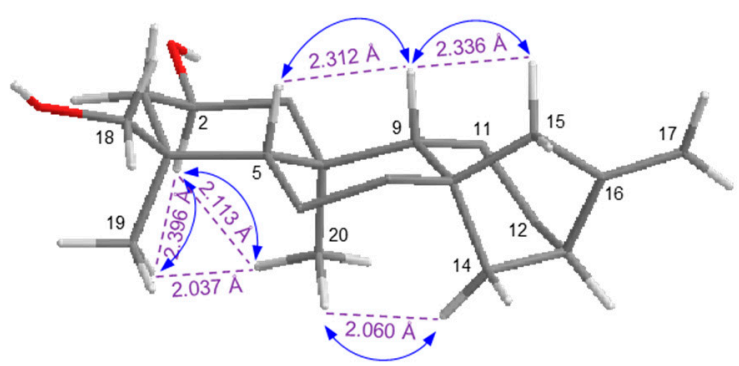

(a)

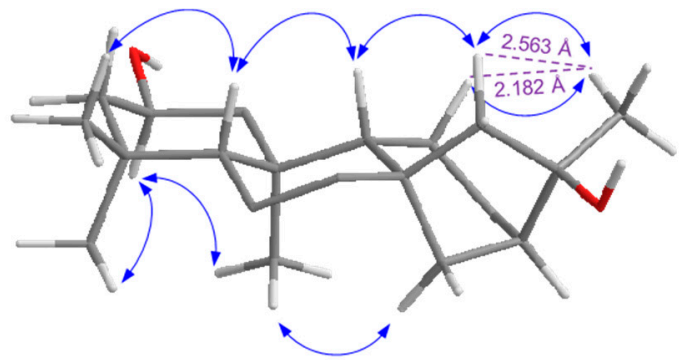

(b)

Figure 3. The NOESY correlations of each aglycone of compounds 4 (a) and $\mathbf{1 0}(\mathbf{b})$.

Compound 10 was obtained as a white amorphous powder, and its molecular formula was assigned as $\mathrm{C}_{32} \mathrm{H}_{54} \mathrm{O}_{12}$ according to the HR-ESI-MS peak at $\mathrm{m} / z 653.3516[\mathrm{M}+\mathrm{Na}]^{+}$(calcd. for $\mathrm{C}_{32} \mathrm{H}_{54} \mathrm{O}_{12} \mathrm{Na}$, 653. 3513). The ${ }^{1} \mathrm{H}$ - and ${ }^{13} \mathrm{C}-\mathrm{NMR}$ spectrum data of $\mathbf{1 0}$ showed the presence of an ent-kaurane diterpene skeleton exhibiting characteristic signals including four tertiary methyl carbons $\left(\delta_{\mathrm{C}} 35.1,23.5,22.2,20.2\right)$ and two $\beta$-D-glucopyranose moieties $\left[\delta_{\mathrm{H}} 4.36\left(2 \mathrm{H}, \mathrm{d}, J=7.8 \mathrm{~Hz}, \mathrm{H}-1^{\prime}, \mathrm{H}-1^{\prime \prime}\right) ; \delta_{\mathrm{C}}\right.$ 103.4, 100.1, 79.1, 78.9, 78.6. 78.4, 76.0, 75.9, 72.6, 72.5, 63.6, 63.5]. Comparison of the ${ }^{13} \mathrm{C}-\mathrm{NMR}$ data for the aglycone of $\mathbf{1 0}$ with that of $\mathbf{4}$ revealed quite similar patterns, except for the fact that $\mathbf{1 0}$ had a methyl signal at C-18 $\left(\delta_{C} 35.1\right)$ instead of an oxymethylene and exhibited no olefinic group at C-16 and C-17 but instead an oxygenated quaternary carbon $\left(\delta_{C} 89.3, C-16\right)$ with a tertiary methyl carbon $\left(\delta_{C} 22.2\right.$, $\mathrm{C}-17)$. When comparing the $1 \mathrm{D}$ and $2 \mathrm{D}-\mathrm{NMR}$ data of $\mathbf{1 0}$ with its aglycone, the known compound $2 \beta, 16 \alpha$-dihydroxy-ent-kaurane (9) [16], the two glucose groups are suggested to be linked to C-2 and C-16 from the significant downfield shift of C-2 $\left(\delta_{C} 75.0\right)$ and C-16 $\left(\delta_{C}\right.$ 89.3) (Table 1 and Tables S1 and S2). The HMBC cross-peak correlations from the anomeric proton $\left(\delta_{\mathrm{H}} 4.36\left(2 \mathrm{H}, \mathrm{d}, J=7.8 \mathrm{~Hz}, \mathrm{H}-1^{\prime}\right.\right.$, $\left.\mathrm{H}-1^{\prime \prime}\right)$ ) to $\mathrm{C}-2$ and $\mathrm{C}-16$ support the assignment above. The $\beta$-orientation of the $O$-Glc group at $\mathrm{C}-2$ and the $\alpha$-orientation of another $O$-Glc group at $\mathrm{C}-16$ were determined by the NOESY correlations from $\mathrm{H}-2$ to $\mathrm{H}-1 \mathrm{a}, \mathrm{H}-3 \mathrm{a}, \mathrm{CH}_{3}-19$, and $\mathrm{CH}_{3}-20$ and from $\mathrm{CH}_{3}-17$ to $\mathrm{H}-11 \mathrm{~b}$ and $\mathrm{H}-15 \mathrm{a}, \mathrm{H}-15 \mathrm{a}$ to $\mathrm{H}-9$, $\mathrm{H}-9$ to $\mathrm{H}-5$, and $\mathrm{H}-5$ to $\mathrm{CH}_{3}-18$, respectively (Figure 3b). Additionally, the calculated interatomic distances from $\mathrm{CH}_{3}-17$ to $\mathrm{H}-11 \mathrm{~b}$ and $\mathrm{H}-15 \mathrm{a}$ on the 3D structure of the aglycone of $\mathbf{1 0}$ are $2.182 \AA$ and $2.563 \AA$, respectively (Figure 3a), whereas the distances would be over the detection limit of the NOESY correlation ( $5 \AA$ ) when assuming the $O$-glucose group at $C-16$ has a $\beta$-orientation [17]. Thus, from the observation of the NOESY correlation, the location of where the glucose is attached and its relative configuration for this molecule were confirmed. The CD spectral data of $\mathbf{1 0}$ have features similar to those of $\mathbf{4}$, which indicate that $\mathbf{1 0}$ has the same stereochemistry as $\mathbf{4}$ (Figure S14). Consequently, the structure of 10 was determined to be $2 \beta, 16 \alpha$-dihydroxy-ent-kaurane 2,16-di-O- $\beta$-D-glucopyranoside. 
Table 1. ${ }^{1} \mathrm{H}$ - and ${ }^{13} \mathrm{C}-\mathrm{NMR}$ spectral data of $\mathbf{4}, \mathbf{1 0}$ and 12 in $\mathrm{CD}_{3} \mathrm{OD}(\delta$ in ppm; $J$ in $\mathrm{Hz})$.

\begin{tabular}{|c|c|c|c|c|c|c|}
\hline \multirow{2}{*}{ Position } & \multicolumn{2}{|l|}{$4^{a}$} & \multicolumn{2}{|l|}{$10^{b}$} & \multicolumn{2}{|l|}{$12^{a}$} \\
\hline & $\delta_{\mathrm{H}}(J$ in $\mathrm{Hz})$ & $\delta_{C}$ & $\delta_{\mathrm{H}}(J$ in $\mathrm{Hz})$ & $\delta_{C}$ & $\delta_{\mathrm{H}}(J$ in $\mathrm{Hz})$ & $\delta_{\mathrm{C}}$ \\
\hline $1 \mathrm{a}, 1 \mathrm{~b}$ & $2.30, \mathrm{~m}, 0.76, \mathrm{t}(11.9)$ & 49.1 & $2.28, \mathrm{~m}, 0.77, \mathrm{t}(11.9)$ & 49.4 & $2.28, \mathrm{~m}, 0.77, \mathrm{t}(11.4)$ & 50.1 \\
\hline 2 & $4.08, \mathrm{~m}$ & 74.9 & $4.02, \mathrm{~m}$ & 75.0 & $4.01, \mathrm{~m}$ & 74.9 \\
\hline $3 a, 3 b$ & $1.72, \mathrm{~m}, 1.37, \mathrm{~m}$ & 43.0 & $1.88, \mathrm{~m}, 1.13, \mathrm{~m}$ & 49.1 & $1.87, \mathrm{~m}, 1.12, \mathrm{~m}$ & 49.6 \\
\hline 4 & & 40.7 & & 36.4 & & 36.4 \\
\hline 5 & $1.20, \mathrm{~m}$ & 50.5 & $0.82, \mathrm{~m}$ & 58.0 & $0.85, \mathrm{~m}$ & 58.0 \\
\hline $6 a, 6 b$ & $1.55, \mathrm{~m}, 1.31, \mathrm{~m}$ & 20.7 & $1.66, \mathrm{~m}, 1.38, \mathrm{~m}$ & 22.0 & $1.59, \mathrm{~m}, 1.35, \mathrm{~m}$ & 22.0 \\
\hline $7 \mathrm{a}, 7 \mathrm{~b}$ & $1.63, \mathrm{~m}, 1.52, \mathrm{~m}$ & 36.8 & $1.65, \mathrm{~m}, 1.46, \mathrm{~m}$ & 43.5 & $1.60, \mathrm{~m}, 1.50, \mathrm{~m}$ & 43.9 \\
\hline 8 & & 49.7 & & 47.2 & & 46.5 \\
\hline 9 & $1.10, \mathrm{~m}$ & 56.6 & $1.04, \mathrm{~m}$ & 59.1 & $1.06, \mathrm{~m}$ & 59.0 \\
\hline 10 & & 42.9 & & 42.9 & & 42.9 \\
\hline $11 a, 11 b$ & $1.65, \mathrm{~m}, 1.48, \mathrm{~m}$ & 20.1 & $1.66, \mathrm{~m}, 1.58, \mathrm{~m}$ & 20.2 & $1.68, \mathrm{~m}, 1.56, \mathrm{~m}$ & 20.3 \\
\hline $12 a, 12 b$ & $1.68, \mathrm{~m}, 1.46, \mathrm{~m}$ & 34.7 & $1.58, \mathrm{~m}$ & 28.6 & $1.65, \mathrm{~m}, 1.55, \mathrm{~m}$ & 28.1 \\
\hline 13 & 2.70, br s & 44.5 & 2.11 , br s & 48.2 & $2.02, \mathrm{br} \mathrm{s}$ & 47.2 \\
\hline $14 a, 14 b$ & $1.90, \mathrm{~d}(11.6), 1.38, \mathrm{~m}$ & 38.2 & $1.82, \mathrm{~d}(11.5), 1.73, \mathrm{dd}(11.5,4.1)$ & 39.0 & $1.90, \mathrm{~m}, 1.61, \mathrm{~m}$ & 39.1 \\
\hline $15,15 b$ & 3.76, br s & 84.6 & $1.88, \mathrm{~d}(14.2), 1.41, \mathrm{~d}(14.2)$ & 57.4 & $1.53, \mathrm{~m}, 1.40, \mathrm{~m}$ & 54.8 \\
\hline 16 & & 161.3 & & 89.3 & & 83.6 \\
\hline $17,17 \mathrm{~b}$ & $5.17, \mathrm{~s}, 5.06, \mathrm{~s}$ & 109.8 & $1.38, \mathrm{~s}$ & 22.2 & 3.69, d (11.4), 3.58, d (11.4) & 67.7 \\
\hline $18,18 b$ & 3.37, d (11.0), 3.06, d (11.0) & 72.7 & $0.92, \mathrm{~s}$ & 35.1 & $0.93, \mathrm{~s}$ & 35.0 \\
\hline 19 & $0.79, \mathrm{~s}$ & 19.5 & $0.86, \mathrm{~s}$ & 23.5 & $0.86, \mathrm{~s}$ & 23.5 \\
\hline 20 & $1.13, \mathrm{~s}$ & 20.6 & $1.09, \mathrm{~s}$ & 20.2 & $1.09, \mathrm{~s}$ & 20.2 \\
\hline $1^{\prime}$ & $4.38, \mathrm{~d}(7.8)$ & 103.3 & $4.36, \mathrm{~d}(7.8)$ & 103.4 & & 103.3 \\
\hline $2^{\prime}$ & $3.13, \mathrm{t}(8.3)$ & 75.9 & $3.10, \mathrm{t}(8.2)$ & 76.0 & & 76.0 \\
\hline $3^{\prime}$ & $3.26, \mathrm{~m}$ & 78.6 & $3.26, \mathrm{~m}$ & 78.6 & & 78.6 \\
\hline $4^{\prime}$ & $3.27, \mathrm{~m}$ & 72.5 & $3.27, \mathrm{~m}$ & 72.5 & & 72.5 \\
\hline $5^{\prime}$ & $3.35, \mathrm{~m}$ & 78.9 & $3.34, \mathrm{~m}$ & 79.1 & & 78.9 \\
\hline $6^{\prime} \mathrm{a}, 6^{\prime} \mathrm{b}$ & $3.85, \mathrm{~m}, 3.66, \mathrm{dd}(11.0,3.8)$ & 63.6 & $3.85, \mathrm{~m}, 3.78, \mathrm{~m}$ & 63.6 & & 63.6 \\
\hline $1^{\prime \prime}$ & & & $4.36, \mathrm{~d}(7.8)$ & 100.1 & & \\
\hline $2^{\prime \prime}$ & & & $3.12, \mathrm{t}(8.3)$ & 75.9 & & \\
\hline $3 "$ & & & $3.20, \mathrm{~m}$ & 78.4 & & \\
\hline $4^{\prime \prime}$ & & & $3.26, \mathrm{~m}$ & 72.6 & & \\
\hline $5^{\prime \prime}$ & & & $3.35, \mathrm{~m}$ & 78.9 & & \\
\hline $6^{\prime \prime} \mathrm{a}, 6^{\prime \prime} \mathrm{b}$ & & & $3.66, \mathrm{~m}, 3.62, \mathrm{~m}$ & 63.5 & & \\
\hline
\end{tabular}

a ${ }^{1} \mathrm{H}-\mathrm{NMR}$ data were measured at $500 \mathrm{MHz}$, and ${ }^{13} \mathrm{C}-\mathrm{NMR}$ data were measured at $125 \mathrm{MHz}$ in $\mathrm{CD}_{3} \mathrm{OD}$, respectively; ${ }^{\mathrm{1}} \mathrm{H}-\mathrm{NMR}$ data were measured at $600 \mathrm{MHz}$, and ${ }^{13} \mathrm{C}-\mathrm{NMR}$ data were measured at $150 \mathrm{MHz}$ in $\mathrm{CD}_{3} \mathrm{OD}$, respectively. 
Compound $\mathbf{1 2}$ was isolated as a white amorphous powder. The molecular formula of $\mathbf{1 2}$ was determined to be $\mathrm{C}_{26} \mathrm{H}_{44} \mathrm{O}_{8}$ based on the HR-ESI-MS signal at $m / z 483.2931[\mathrm{M}-\mathrm{H}]^{-}$(calcd. for $\mathrm{C}_{26} \mathrm{H}_{43} \mathrm{O}_{8}, 483.2958$ ). Analysis of the ${ }^{1} \mathrm{H}$ - and ${ }^{13} \mathrm{C}-\mathrm{NMR}$ data of $\mathbf{1 2}$ revealed similar patterns to those of compound 10 except for the presence of one glucose moiety $\left(\delta_{C} 103.4,78.9,78.6,76.0,72.5,63.6\right)$ and an oxygenated methylene $\left(\delta_{\mathrm{H}} 3.69(1 \mathrm{H}, \mathrm{d}, J=11.4), 3.58(1 \mathrm{H}, \mathrm{d}, J=11.4) ; \delta_{\mathrm{C}} 67.7\right)$. The HMBC correlations indicate that an oxymethylene is attached to the $C-16$ quaternary carbon $\left(\delta_{C} 83.6\right)$, and a glucose group is connected to C-2. The NOESY correlations from $\mathrm{H}-2$ to $\mathrm{H}-1 \mathrm{a}, \mathrm{H}-3 \mathrm{a}, \mathrm{CH}_{3}-19$, and $\mathrm{CH}_{3}-20$ imply a $\beta$ configuration for the 2-O-glucose, and the correlations from $\mathrm{H}_{2}-17$ to $\mathrm{H}-15 \mathrm{a}, \mathrm{H}-15 \mathrm{a}$ to $\mathrm{H}-9, \mathrm{H}-9$ to $\mathrm{H}-5$, and $\mathrm{H}-5$ to $\mathrm{CH}_{3}-18$ establish an $\alpha$ configuration for the $16-\mathrm{OH}$. In addition, compound $\mathbf{1 2}$ had a similar CD spectra with that of $\mathbf{1 0}$ implying that they have the same absolute configurations (Figure S21). Based on the above data, 12 was determined to be $2 \beta, 16 \alpha, 17$-trihydroxy-ent-kaurane 2-O- $\beta$-D-glucopyranoside.

The nine known compounds were identified as $2 \beta, 15 \alpha$-dihydroxy-ent-kaur-16-ene (1) [16], creticoside A (2) [16], pterokaurane $\mathrm{M}_{1}$ (3) [8], 2 $\beta, 15 \alpha$,19-trihydroxy-ent-kaur-16-ene 2-O- $\beta$-D-gluco-pyranoside (5) [18], $2 \beta, 6 \beta, 15 \alpha$-trihydroxy-ent-kaur-16-ene (6) [18], pterokaurane $P_{1}$ (7) [19], pterokaurane $P_{1}$ 2-O- $\beta$-D-glucopyranoside (8) [19], 2 $\beta, 16 \alpha$-dihydroxy-ent-kaurane (9) [16], and pterokaurane R (11) [20] by comparing their spectroscopic data with values reported in the literature.

\subsection{NO Inhibitory Effects of Ent-kaurane Diterpenoids}

Some studies have reported on the anti-inflammatory activities of diterpenes from various plant extracts [21-25]. However, there have been no reports yet on the effects of ent-kaurane diterpenoids isolated from P. multifida on neuroinflammation. The characteristic feature of the ent-kaurane diterpenes isolated from P. multifida is the presence of a hydroxyl group at C-2 in their chemical structures. In this study, therefore, we evaluated the anti-neuroinflammatory activities of the isolated compounds 1-12 with LPS-activated BV-2 cells as the screening tool (Table 2).

Table 2. Inhibitory activity of compounds 1-12 on NO production in LPS-activated BV-2 cells.

\begin{tabular}{|c|c|c|c|c|c|}
\hline Compound & $\mathrm{IC}_{50}{ }^{\mathrm{a}}(\mu \mathrm{M})$ & Cell Viability ${ }^{b}(\%)$ & Compound & $\mathrm{IC}_{50}{ }^{\mathrm{a}}(\mu \mathrm{M})$ & Cell Viability ${ }^{b}(\%)$ \\
\hline 1 & 13.9 & $90.7 \pm 7.3$ & 7 & 10.8 & $88.7 \pm 2.4$ \\
\hline 2 & 92.0 & $95.7 \pm 4.0$ & 8 & 101.4 & $91.7 \pm 3.7$ \\
\hline 3 & 84.0 & $87.7 \pm 2.9$ & 9 & 121.7 & $97.5 \pm 1.3$ \\
\hline 4 & 148.1 & $90.5 \pm 10.2$ & 10 & 182.2 & $88.2 \pm 8.0$ \\
\hline 5 & 147.9 & $73.6 \pm 2.9$ & 11 & 171.3 & $83.2 \pm 10.2$ \\
\hline \multirow[t]{2}{*}{6} & 137.1 & $85.9 \pm 0.1$ & 12 & 113.7 & $93.6 \pm 8.3$ \\
\hline & & & L-NAME ${ }^{\mathrm{c}}$ & 53.5 & $100.3 \pm 5.0$ \\
\hline
\end{tabular}

\footnotetext{
${ }^{a} \mathrm{IC}_{50}$ value of each compound was defined as the concentration $(\mu \mathrm{M})$ that caused $50 \%$ inhibition of NO production in LPS-stimulated BV-2 cells; ${ }^{\mathrm{b}}$ Cell viability was measured by the MTT assay after treatment with $100 \mu \mathrm{M}$ of each compound for $24 \mathrm{~h}$. Results are expressed as the mean $\pm \mathrm{SD} .{ }^{\mathrm{C}} \mathrm{N}_{\omega}$-nitro-L-arginine methyl ester (L-NAME) was used as a positive control.
}

Among the isolates, $\mathbf{1}$ and $\mathbf{7}$ showed significant inhibition of NO production in the LPS-activated BV-2 cells with an $\mathrm{IC}_{50}$ value of $13.9 \mu \mathrm{M}$ and $10.8 \mu \mathrm{M}$, respectively, without any cytotoxicity. Especially, $\mathbf{1}$ and $\mathbf{7}$ showed higher NO inhibitory activities than that of previously reported ent-kaurane diterpenoids in BV-2 microglia cells [24]. It was shown that the compounds with a hydroxyl group at $\mathrm{C}-2$ have more potent NO inhibitory activities than their glycosides $(1>2,3>4,7>8$, and $9>10)$. In addition, the compounds with a hydroxyl group at C-6 exhibited decreased inhibitory activity against NO production $(\mathbf{1}>\mathbf{6})$. Therefore, the above data suggest that the NO inhibitory effect of the ent-kaurane diterpenoids is related to the degree of hydroxylation and substituted moieties.

Because LPS is known to induce the production of pro-inflammatory mediators by cyclooxygenase- 2 (COX-2) which is a pro-inflammatory enzyme that has a central role in the inflammatory response by converting arachidonic acids into prostaglandins (PGs) [26], the effects of $\mathbf{1}$ and $\mathbf{7}$, which showed 
a significant NO inhibitory activity on LPS-induced COX-2 expression in activated BV-2 microglia cells, were evaluated by western blot analysis (Figure 4a). Our results show that the protein level of COX-2 increased by the LPS treatment was down-regulated by the treatments of 1 and 7 . In further examination of the effect of $\mathbf{1}$ and $\mathbf{7}$ on pro-inflammatory mediators, the level of cytokines including tumor necrosis factor (TNF)- $\alpha$, interleukin (IL)-1 $\beta$, and IL-6, and PGE 2 enzyme in LPS-activated BV-2 microglia cells were effectively decreased by pre-treatment with $\mathbf{1}$ and $\mathbf{7}$ in a dose-dependent manner (Figure 4b). These results suggest that 1 and 7 suppress NO production by inhibiting COX-2 protein expression and pro-inflammatory mediators. To the best of our knowledge, this is the first report for the anti-neuroinflammatory effects of ent-kaurane diterpenoids from P. multifida in BV-2 microglia.
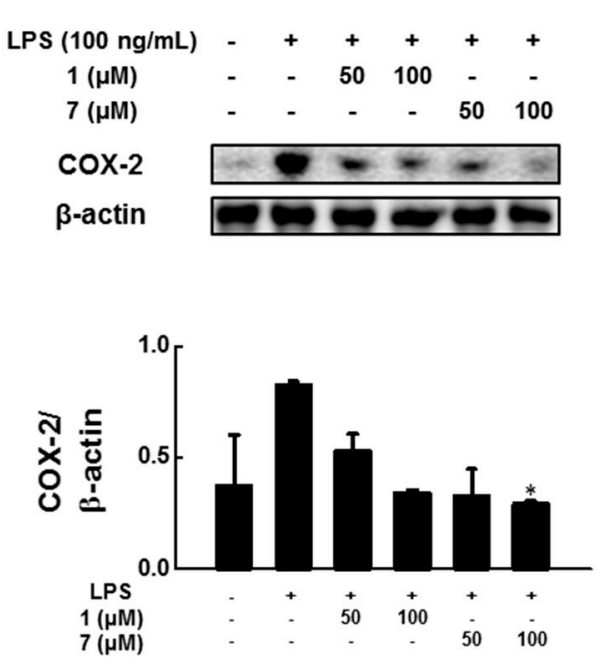

(a)
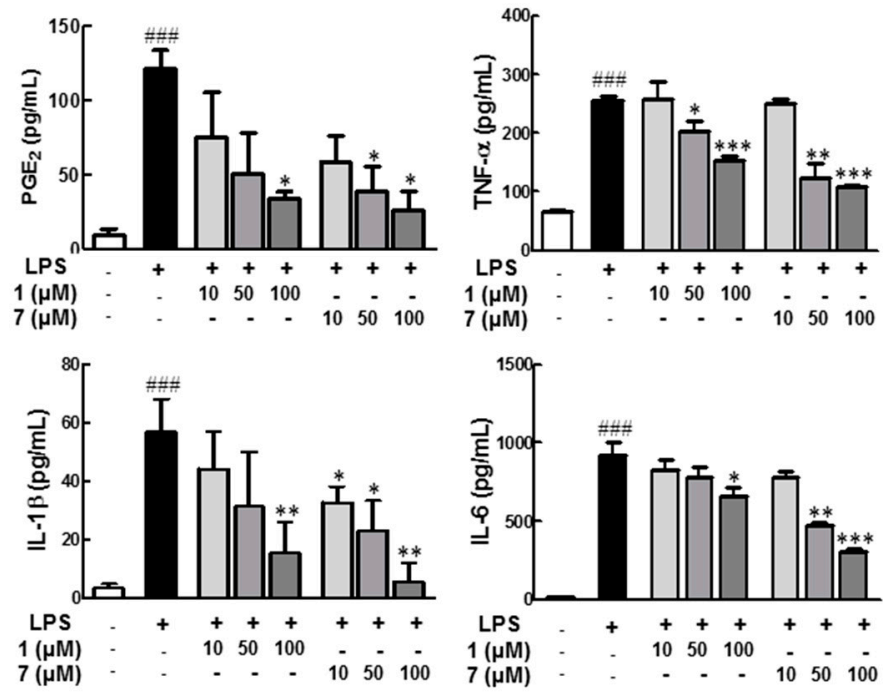

(b)

Figure 4. Anti-neuroinflammatory effects of compounds 1 and 7 in lipopolysaccharide (LPS)-activated BV-2 microglia. (a) The expression of cyclooxygenase (COX)-2 in LPS-activated BV-2 microglia in western blot. The data represent the mean \pm SD. ${ }^{*} p<0.1$ versus LPS-treated group $(n=2)$. Representatives of two independent experiments with similar results are shown; (b) The effects of compounds 1 and 7 on prostaglandin (PG) $\mathrm{E}_{2}$, tumor necrosis factor (TNF)- $\alpha$, interlukin (IL)- $1 \beta$, and IL-6 production in LPS-activated BV-2 microglia cells. ${ }^{\# \# \# ~} p<0.001$, compared to vehicle, ${ }^{*} p<0.05$, $* * p<0.01$, and ${ }^{* * *} p<0.001$, compared to the LPS-treated group $(n=3)$.

In summary, 12 ent-kaurane diterpene compounds 1-12, including three new compounds 4 , 10, and 12, were isolated from the roots of P. multifida. Among the isolates, compounds 1 and 7 inhibit the production of NO and the pro-inflammatory mediators TNF- $\alpha$, IL-1 $\beta$, IL-6, and PGE 2 as well as the expression of COX-2 in LPS-stimulated BV-2 microglia cells. Although an in-depth in vivo study is needed to fully elucidate the anti-neuroinflammatory mechanisms by ent-kaurane diterpenoids, these findings could be helpful in discovering potential lead compounds for the treatment of neuroinflammatory diseases.

\section{Materials and Methods}

\subsection{General Experimental Procedures}

For the isolation of the compounds from P. multifida, organic solvents such as methanol $(\mathrm{MeOH})$, n-hexane, methylene chloride $\left(\mathrm{CH}_{2} \mathrm{Cl}_{2}\right)$, chloroform $\left(\mathrm{CHCl}_{3}\right)$, ethyl acetate (EtOAc), acetonitrile (ACN) were used (Dae Jung Pure Chemicals, Siheung, Kyunggi, Korea). Silica gel 60 was purchased from Merck (Darmstadt, Germany). Sephadex LH-20 (bead size 25-100 $\mu \mathrm{m}$ ) was purchased from Pharmacia (Uppsala, Sweden). Preparative high performance liquid chromatography (HPLC) was performed 
using a Gilson 321 pump with a Gilson UV/Vis-151 detector (Gilson Inc., Middleton, WI, USA). JEOL LA 300 (300 MHz, JEOL Ltd., Tokyo, Japan), Bruker AMX 500 (500 MHz, Bruker, Billerica, MA, USA), and Bruker Avance 600 (600 MHz) spectrometers were used to record the nuclear magnetic resonance (NMR) spectra. Optical rotations were recorded on a JASCO P-2000 polarimeter (JASCO, Easton, MD, USA). IR spectra were obtained on a JASCO FT/IR-4200 spectrometer, and CD spectra were acquired with a Chirascan CD spectrometer (Applied Photophysics, Surrey, UK). All HR-ESI-MS data were measured on a Waters Xevo G2 QTOF mass spectrometer (Waters Co., Milford, MA, USA).

For the cell culture, Dulbecco's modified Eagle medium (DMEM) with high glucose, fetal bovine serum (FBS) and streptomycin-penicillin (PS) were purchased from HyClone (Logan, UT, USA). 3-(4,5-dimethyl-thiazol-2yl)-2,5-diphenyltetrazolium (MTT), dimethylsulfoxide (DMSO), and lipopolysaccharide (LPS) were obtained from Sigma-Aldrich (St. Louis, MO, USA). Antibodies against cyclooxygenase-2 (COX-2) and $\beta$-actin were obtained from Santa Cruz Biotechnology (Santa Cruz, CA, USA).

\subsection{Plant Materials}

Roots of P. multifida were collected at the Seoul National University Forest and Baegun Mountain, Gwangyang, Korea in July 2013 and air-dried. A voucher specimen (SNU-11204) was deposited in the Herbarium of the Medicinal Plant Garden of the College of Pharmacy, Seoul National University.

\subsection{Extraction and Isolation}

The dried roots of P. multifida (334.0 g) were extracted three times with $80 \% \mathrm{MeOH}(12 \mathrm{~L}$ for $90 \mathrm{~min}$ ) in an ultrasonic apparatus. Once the solvent was removed in vacuo, the extract ( $30.0 \mathrm{~g})$ was suspended in water and partitioned into a $\mathrm{CH}_{2} \mathrm{Cl}_{2}(7.4 \mathrm{~g})$, EtOAc $(2.3 \mathrm{~g})$, and aqueous residue (20.1 g). The $\mathrm{CH}_{2} \mathrm{Cl}_{2}$ layer was suspended in $90 \% \mathrm{MeOH}$ and then partitioned with $n$-hexane yielding a solid residue of $2.1 \mathrm{~g}$ (n-hexane) and $5.3 \mathrm{~g}(90 \% \mathrm{MeOH})$. The $90 \% \mathrm{MeOH}$ fraction was subjected to silica gel column chromatography (CC) eluted with mixtures of $\mathrm{CHCl}_{3}-\mathrm{MeOH}$ (from 100:1 to 0:100, v/v) to yield 25 fractions (MC1 MC25). Fraction MC-8 was purified by semi-preparative HPLC using a YMC Hydrosphere C18-column with an ACN-water (50:50) solvent to yield 7 (15.1 mg). Compound 6 (1.4 mg) was isolated from MC-11 by semi-preparative HPLC (YMC Hydrosphere C18, $250 \times 10 \mathrm{~mm}$, ACN-water, 50:50, $4 \mathrm{~mL} / \mathrm{min}$, UV $210 \mathrm{~nm})$. Compound 1 (22.2 $\mathrm{mg})$ was obtained from MC-17 by recrystallization. Compound $3(3.0 \mathrm{mg})$ was isolated from MC-20 by semi-preparative HPLC (YMC Hydrosphere C18, $250 \times 10 \mathrm{~mm}$, ACN-water, 50:50, $4 \mathrm{~mL} / \mathrm{min}$, UV $210 \mathrm{~nm}$ ). The EtOAc fraction was subjected to silica gel $\mathrm{CC}$ eluted with mixtures of $\mathrm{CHCl}_{3}-\mathrm{MeOH}$ (from 40:1 to 0:100, v/v) to yield 13 fractions (EA1 EA13). Fraction EA-2 was purified by semi-preparative HPLC using a YMC Hydrosphere C18 column with an ACN-water (80:20) solvent to yield 9 (15.1 mg). Compound 12 (4.4 mg) was isolated from EA-8 by semi-preparative HPLC (YMC Hydrosphere C18, $250 \times 10 \mathrm{~mm}$, ACN-water, 20:80 $\rightarrow 30: 70,4 \mathrm{~mL} / \mathrm{min}$, UV $210 \mathrm{~nm}$ ). Compound 2 (11.2 mg) was obtained from EA-11 by semi-preparative HPLC (YMC Hydrosphere C18, $250 \times 10 \mathrm{~mm}$, ACN-Water, 48:52, $4 \mathrm{~mL} / \mathrm{min}$, UV $210 \mathrm{~nm}$ ). The aqueous fraction was subjected to a HP-20 column eluted with water containing increasing amounts of methanol to obtain 5 subfractions (0M, 25M, 50M, 75M, and 100M) subfraction $50 \mathrm{M}$ was further separated into fifteen fractions (50M-1 50M-15) using silica gel CC eluted with mixtures of $\mathrm{CHCl}_{3}-\mathrm{MeOH}$ (from 20:1 to 0:100, v/v). Compound 8 (38.0 $\mathrm{mg}$ ) was obtained from the 50M-11 fraction by CC on Sephadex LH-20 with MeOH. Compounds 4 (25.4 mg), 5 (6.5 mg), and 10 $(6.1 \mathrm{mg}$ ) were isolated from 50M-14 by semi-preparative HPLC (YMC Hydrosphere C18, $250 \times 10 \mathrm{~mm}$, ACN-water, 48:52, $4 \mathrm{~mL} / \mathrm{min}$, UV $210 \mathrm{~nm}$ ). Fraction $75 \mathrm{M}$ was subjected to silica gel CC eluted with mixtures of $\mathrm{CHCl}_{3}-\mathrm{MeOH}$ (from 30:1 to 1:1, v/v) to yield 18 fractions (75M-1 75M-18). Compound 11 (4.1 mg) was obtained from $75 \mathrm{M}-7$ by recrystallization. 


\subsection{Acid Hydrolysis of 4, $\mathbf{1 0}$ and $\mathbf{1 2}$}

Each compound (4, $1.0 \mathrm{mg} ; \mathbf{1 0}, 1.0 \mathrm{mg} ; \mathbf{1 2}, 1.0 \mathrm{mg})$ was refluxed in $1 \% \mathrm{HCl}(1 \mathrm{~mL})$ for $1 \mathrm{~h}$ to yield aglycone and sugar. The reaction mixture was extracted with EtOAc $(5 \mathrm{~mL})$ to yield an aqueous fraction containing the sugar and the EtOAc fraction containing the aglycone. The aqueous fraction was concentrated and loaded onto silica gel TLC plates with EtOAc-MeOH- $\mathrm{H}_{2} \mathrm{O}-\mathrm{AcOH}$ (13:3:3:4), using $20 \% \mathrm{H}_{2} \mathrm{SO}_{4}$. The sugars of 4,10 , and 12 were identified as glucose by co-TLC comparison with an authentic sample. The absolute configuration of the glucose moiety in compounds 4, 10 and 12 was determined by the method of Tanaka et al. [14] Each glucose was detected by reversed-phase HPLC using a XBridge C18-column $\left(250 \mathrm{~mm} \times 4.6 \mathrm{~mm}\right.$ i.d., $5 \mu \mathrm{m}$, Waters) with a $\mathrm{MeCN}_{-} \mathrm{H}_{2} \mathrm{O}(25: 75, v / v)$ solvent system containing $50 \mathrm{mM} \mathrm{H}_{3} \mathrm{PO}_{4}$ (flow rate $1 \mathrm{~mL} / \mathrm{min}$ ). The derivatives of D-glucose in 4, 10, and 12 were identified by comparison of their retention times with those of authentic samples treated in the same manner as described above $\left(\underline{t}_{R}, \mathrm{D}\right.$-glucose derivatives $\left.12.62 \mathrm{~min}\right)$.

\subsection{Cell Culture}

The BV-2 mouse microglial cells were generously provided by Dr. Sun Yeou Kim at Kyunghee University (Suwon, Korea). The cells were maintained in DMEM containing 10\% FBS with $1 \%$ PS at $37{ }^{\circ} \mathrm{C}$ in a humidified atmosphere of $95 \%$ air and $5 \% \mathrm{CO}_{2}$. All tested fractions and samples were dissolved in DMSO (final concentration in cultures $\leq 0.1 \%$ ).

\subsection{NO Production Assay and Cell Viability Assay}

To evaluate NO production, we seeded BV-2 cells in 96-well plates $\left(4 \times 10^{5}\right.$ cells $/ \mathrm{mL}$ ) for $24 \mathrm{~h}$ and then treated them with various concentrations of the samples for $1 \mathrm{~h}$ before exposure to $100 \mathrm{ng} / \mathrm{mL}$ of LPS. After the $24 \mathrm{~h}$ incubation, the nitrite in the culture media was measured to assess NO production in the BV-2 cells with the Griess reagent ( $1 \%$ sulfanilamide and $0.1 \%$ naphtylethylenediamine dihydrochloride in $2 \%$ phosphoric acid). In 96-well plates, $100 \mu \mathrm{L}$ of sample aliquots were mixed with $100 \mu \mathrm{L}$ of Griess reagent and incubated at room temperature for $15 \mathrm{~min}$. The absorbance at $550 \mathrm{~nm}$ was measured on a microplate reader. The concentration was determined with a nitrite standard curve. Cell viability was assessed by the MTT assay. After exposing the cells to $2 \mathrm{mg} / \mathrm{mL}$ MTT for $2 \mathrm{~h}$, the absorbance was measured by an ELISA plate reader at $562 \mathrm{~nm}$.

\section{7. $P G E_{2}, T N F-\alpha, I L-1 \beta$, and IL-6 ELISA Assay}

BV-2 microglial cells were cultured in 96-well plates, preincubated for $30 \mathrm{~min}$. with different concentrations of compounds 1 and 7 and then stimulated for $24 \mathrm{~h}$ with LPS (Sigma-Aldrich Co.). Supernatant from the culture $(100 \mu \mathrm{L})$ was collected to determine the concentration of PGE $2, \mathrm{TNF} \alpha$, IL-1 $\beta$, and IL-6, respectively, with ELISA kits (TNF- $\alpha$, Abcam, Cambridge, MA, USA; PGE 2 , IL-1 $\beta$, and IL-6, R\&D Systems, Minneapolis, MN, USA).

\subsection{Western Blot Analysis}

Cells were harvested and lysed with radioimmunoprecipitation (RIPA) buffer (Bio-Rad, Hercules, CA USA). Cell lysates were centrifuged, and the supernatant was collected. The protein concentration was determined by protein assay reagents (Bio-Rad). The proteins were separated onto $10 \%$ SDS-polyacrylamide gel and transferred to polyvinylidene fluoride (PVDF) membrane. The membranes were blocked with 5\% non-fat dry milk in Tris-buffered saline with $0.1 \%$ Tween-20 (TBS-T) buffer for $1 \mathrm{~h}$ at room temperature and then incubated with primary antibodies in TBS-T buffer containing $1 \%$ non-fat dry milk overnight at $4{ }^{\circ} \mathrm{C}$. The membranes were washed with TBS-T buffer and incubated with goat anti-rabbit or anti-mouse horseradish peroxidase-conjugated IgG secondary antibodies from Santa Cruz Biotechnology (Santa Cruz, CA, USA) for $2 \mathrm{~h}$. The membranes were washed with TBS-T buffer, and the antigen-antibody complex was detected with an enhanced chemiluminescence detection system (GE Healthcare, Milwaukee, MI, USA). 


\subsection{Statistical Analysis}

Data were evaluated for statistical significance with one way ANOVA using the IBM SPSS Statistics 23 package. The data were considered statistically significant with $*<0.05,{ }^{* *} p<0.01$, and *** $p<0.001$.

Supplementary Materials: Supplementary materials can be accessed at: http://www.mdpi.com/1420-3049/22/ $1 / 27 / \mathrm{s} 1$.

Acknowledgments: We especially thank Gi Ho Ha and Hakgi Park at Seoul National University Forest and Sang il Han at Seoul National University Medicinal Herb Garden for providing and collecting the plant material, P. multifida. This research was supported by the Basic Science Research Program through the National Research Foundation of Korea (NRF), which was funded by the Ministry of Science, ICT and Future Planning (NRF-2015M3A9A5030733).

Author Contributions: J.W.K. and S.H.S. designed the experiments; J.W.K. performed the experiments; J.W.K., J.Y.S. and S.H.S. analyzed the data; W.K.O. and S.H.S. contributed reagents/materials/analysis tools; J.W.K. and S.H.S. wrote the paper. All authors read and approved the final manuscript.

Conflicts of Interest: The authors declare no conflict of interest.

\section{References}

1. Cuadros, M.A.; Navascués, J. The origin and differentiation of microglial cells during development. Prog. Neurobiol. 1998, 56, 173-189. [CrossRef]

2. Bugnon, O.; Schaad, N.C.; Schorderet, M. Nitric oxide modulates endogenous dopamine release in bovine retina. Neuroreport 1994, 5, 401-404. [CrossRef] [PubMed]

3. Dawson, V.; Brahmbhatt, H.; Mong, J.; Dawson, T. Expression of inducible nitric oxide synthase causes delayed neurotoxicity in primary mixed neuronal-glial cortical cultures. Neuropharmacology 1994, 33, 1425-1430. [CrossRef]

4. Eikelenboom, P.; Veerhuis, R. The role of complement and activated microglia in the pathogenesis of Alzheimer's disease. Neurobiol. Aging 1996, 17, 673-680. [CrossRef]

5. Lu, H.; Hu, J.; Zhang, L.X.; Tan, R.X. Bioactive constituents from Pteris multifida. Planta Med. 1999, 65, 586-587. [CrossRef] [PubMed]

6. Harinantenaina, L.; Matsunami, K.; Otsuka, H. Chemical and biologically active constituents of Pteris multifida. J. Nat. Med. 2008, 62, 452-455. [CrossRef] [PubMed]

7. $\mathrm{Hu}, \mathrm{H}$; Zheng, $\mathrm{X}$; $\mathrm{Hu}, \mathrm{H}$; $\mathrm{Cao}, \mathrm{H}$. Three antibacterial compounds from the roots of Pteris multifida. Chem. Nat. Compd. 2009, 45, 45-48.

8. Ge, X.; Ye, G.; Li, P.; Tang, W.J.; Gao, J.L.; Zhao, W.M. Cytotoxic diterpenoids and sesquiterpenoids from Pteris multifida. J. Nat. Prod. 2008, 71, 227-231. [CrossRef] [PubMed]

9. Hu, H.; Zheng, X. Studies on the chemical compositions of Pteris Multifida Poir. Tianran Chanwu Yanjiu Yu Kaifa 2004, 16, 379-382.

10. Ni, G.; Fu, N.J.; Zhang, D.; Yang, H.Z.; Chen, X.G.; Yu, D.Q. An unusual dihydrobenzofuroisocoumarin and ent-kaurane diterpenoids from Pteris multifida. J. Asian Nat. Prod. Res. 2015, 17, 423-429. [CrossRef] [PubMed]

11. Yu, C.; Chen, J.; Huang, L. A study on the antitumour effect of total flavonoids from Pteris multifida Poir in H22 tumour-bearing mice. Afr. J. Tradit. Complement. Altern. Med. 2013, 10, 459-463. [CrossRef] [PubMed]

12. Wang, T.C.; Lin, C.C.; Lee, H.I.; Yang, C.; Yang, C.C. Anti-hyperlipidemic activity of spider brake (Pteris multifida) with rats fed a high cholesterol diet. Pharm. Biol. 2010, 48, 221-226. [CrossRef] [PubMed]

13. Wang, T.C.; Ti, M.C.; Lo, S.C.; Yang, C.C. Free radical-scavenging activity of aqueous extract of Pteris multifida Poiret. Fitoterapia 2007, 78, 248-249. [CrossRef] [PubMed]

14. Tanaka, T.; Nakashima, T.; Ueda, T.; Tomii, K.; Kouno, I. Facile discrimination of aldose enantiomers by reversed-phase HPLC. Chem. Pharm. Bull. 2007, 55, 899-901. [CrossRef] [PubMed]

15. Ding, G.; Fei, J.; Wang, J.; Xie, Y.; Li, R.; Gong, N.; Lv, Y.; Yu, C.; Zou, Z. Fimbriatols A-J, Highly Oxidized ent-Kaurane Diterpenoids from Traditional Chinese Plant Flickingeria fimbriata (B1.) Hawkes. Sci. Rep. 2016, 6, 30560. [CrossRef] [PubMed] 
16. Murakami, T.; Maehashi, H.; Tanaka, N.; Satake, T.; Kuraishi, T.; Komazawa, Y.; Saiki, Y.; Chen, C. Chemical and chemotaxonomical studies of Filices. 55. Constituents of several species of Pteris. Yakugaku Zasshi 1985, 105, 640-648.

17. Wang, C.M.; Hsu, Y.M.; Jhan, Y.L.; Tsai, S.J.; Lin, S.X.; Su, C.H.; Chou, C.H. Structure Elucidation of Procyanidins Isolated from Rhododendron formosanum and Their Anti-Oxidative and Anti-Bacterial Activities. Molecules 2015, 20, 12787-12803. [CrossRef] [PubMed]

18. Hakamatsuka, T.; Tanaka, D.; Namatame, Y.; Wada, H.; Tanaka, N. Four new ent-kaurane glycosides from Pteris cretica. Nat. Med. 1997, 51, 278-280.

19. Tanaka, N.; Nakatani, K.; Murakami, T.; Saiki, Y.; Chen, C. Chemical and chemotaxonomical studies of the Pteris family and related families (Pteridaceae), XXI. Chemical studies of the contents of Pteris plumbaea Christ. Chem. Pharm. Bull. 1978, 26, 3260-3264. [CrossRef]

20. Tanaka, N.; Kudo, M.; Taniguchi, T.; Murakami, T.; Saiki, Y.; Chen, C. Chemical and chemotaxonomical studies of the family Pteris and related families (Pteridaceae). XVIII. Chemical study of the constituents of Pteris ryukyuensis Tagawa and Pteris longipinna Hayata. Chem. Pharm. Bull. 1978, 26, 1339-1342. [CrossRef]

21. Yeh, S.H.; Chang, F.R.; Wu, Y.C.; Yang, Y.L.; Zhuo, S.K.; Hwang, T.L. An anti-inflammatory ent-kaurane from the stems of Annona squamosa that inhibits various human neutrophil functions. Planta Med. 2005, 71, 904-909. [CrossRef] [PubMed]

22. Aquila, S.; Weng, Z.Y.; Zeng, Y.Q.; Sun, H.D.; Ríos, J.L. Inhibition of NF-kB activation and iNOS induction by ent-kaurane diterpenoids in LPS-stimulated RAW264.7 murine macrophages. J. Nat. Prod. 2009, 72, 1269-1272. [CrossRef] [PubMed]

23. Kuo, P.C.; Yang, M.L.; Hwang, T.L.; Lai, Y.Y.; Li, Y.C.; Thang, T.D.; Wu, T.S. Anti-inflammatory diterpenoids from Croton tonkinensis. J. Nat. Prod. 2013, 76, 230-236. [CrossRef] [PubMed]

24. Lee, M.; Kim, S.H.; Lee, H.K.; Cho, Y.; Kang, J.; Sung, S.H. ent-kaurane and ent-pimarane diterpenes from Siegesbeckia pubescens inhibit lipopolysaccharide-induced nitric oxide production in BV2 microglia. Biol. Pharm. Bull. 2014, 37, 152-157. [CrossRef] [PubMed]

25. Nhiem, N.X.; Hien, N.T.; Tai, B.H.; Anh, H.T.; Hang, D.T.; Quang, T.H.; Kiem, P.V.; Minh, C.V.; Ko, W.; Lee, S.; et al. New ent-kauranes from the fruits of Annona glabra and their inhibitory nitric oxide production in LPS-stimulated RAW264.7 macrophages. Bioorg. Med. Chem. Lett. 2015, 25, 254-258. [CrossRef] [PubMed]

26. Wang, H.; Liu, Y.; Zhang, J.; Xu, J.; Cui, C.A.; Guo, Y.; Jin, D.Q. 15-O-Acetyl-3-O-benzoylcharaciol and helioscopinolide A, two diterpenes isolated from Euphorbia helioscopia suppress microglia activation. Neurosci. Lett. 2016, 612, 149-154. [CrossRef] [PubMed]

Sample Availability: Not available.

(C) 2016 by the authors; licensee MDPI, Basel, Switzerland. This article is an open access article distributed under the terms and conditions of the Creative Commons Attribution (CC-BY) license (http://creativecommons.org/licenses/by/4.0/). 